\title{
KAJIAN MODEL PEMBELAJARAN RESIPROKAL TERHADAP KETERAMPILAN PASSING BOLA BASKET PADA KELAS X SEKOLAH MENENGAH KEJURUAN SWASTA AL-FATTAH MEDAN (Penelitian Masa Pandemi Corona Virus Desease-19)
}

\author{
Josua Anugrah Pardede1, Liliana Puspa Sari² \\ 1,2 Sekolah Tinggi Olahraga dan Kesehatan Bina Guna, Indonesia \\ Jl. Aluminium Raya No. 77, Tanjung Mulia, Medan, Sumatera Utara \\ Email : lili.binaguna@gmail.com
}

\begin{abstract}
ABSTRAK
Penelitian ini bertujuan untuk mengetahui kajian analisis yang berkaitan dengan konsep model pembelajaran picture and picture terhadap dampak keterampilan dribbling sepak bola tingkat Sekolah Dasar. Konsep yang digagas adalah untuk menemukan pembahasan unsur karakteristik dari konsep model pembelajaran picture and picture dan keterampilan dribbling sepak bola, kemudian dapat menjadi rekomendasi pada sekolah untuk menerapkan hasil kajian sebagai peningkatan kompetensi belajar siswa mata pelajaran Pendidikan Jasmani Olahraga dan Kesehatan. Penelitian ini menggunakan desain penelitian deskriptif kualitatif. Desain deskriptif kualitatif diterapkan dengan melakukan analisis peneliti teori dasar. Penelitian yang dilaksanakan pada masa pandemi Corona Virus Desease 2019 (Covid-19) yakni melakukan kajian yang berkaitan dengan model pembelajaran picture and picture dan keterampilan dribbling sepak bola tingkat Sekolah Dasar. Data penelitian diperoleh melalui kajian analisis secara mendalam pada 3 jurnal nasional tentang konsep dan bentuk model pembelajaran picture and picture, dan 3 jurnal nasional tentang keterampilan dribbling sepak bola tingkat Sekolah Dasar. Hasil analisis kajian menunjukkan bahwa model pembelajaran reciprocal memiliki karakteristik yang sesuai dengan karakteristik siswa sekolah menengah kejuruan. Perpaduan yang diperoleh mewujudkan implementasi pembelajaran dengan kegiatan belajar membagi peran kepada siswa yaitu satu sebagai peraga dan lainnya menjadi pengamat, begitu juga dengan sebaliknya. Siswa yang menjadi peraga, menerapkan teknik passing bola basket dengan sambal memberikan penjelasan terkait gerakan yang dilakukan, sedangkan untuk pengamat hanya bertugas menerima bola saja dan mengembalikan bola dengan cara biasa (bukan dengan teknik passing). Kesimpulan terkait kajian adalah penerapan model pembelajaran resiprokal memiliki peran dalam meningkatkan hasil belajar teknik passing bola basket dan dapat diterapkan pada siswa kelas X SMK Swasta Al-Fattah Medan. Bentuk implementasi yang dapat dilakukan dalam materi passing bola basket dengan menggunakan model pembelajaran resiprocal adalah : (1) Siswa diberikan kemandirian untuk membentuk kelompok (pasangan); (2) Membentuk susunan barisan sesuai kebutuhan dan situasi lingkungan sekolah (lapangan); dan (3) Penerapan pergantian peraga dan pengamat ditandai dengan aba-aba peluit sebagai isyarat. Dengan menerapkan bentuk implementasi, maka tujuan dalam mencapai hasil belajar passing bola basket, dapat diwujudkan dengan model pembelajaran resiprocal.
\end{abstract}

Kata kunci: Kajian, Resiprokal, Passing Bola Basket, Covid-19

\section{ABSTRACT}


This study aims to determine the analysis related to the concept of the picture and picture learning model on the impact of soccer dribbling skills at the elementary school level. The concept that was initiated was to find a discussion of the characteristic elements of the picture and picture learning model concept and soccer dribbling skills, then it could become a recommendation for schools to apply the results of the study as an increase in student learning competence in the subjects of Physical Education, Sports and Health. This study used a qualitative descriptive research design. A qualitative descriptive design is applied by conducting a basic theory research analysis. Research carried out during the Corona Virus Desease 2019 (Covid-19) pandemic was to conduct studies related to the picture and picture learning model and soccer dribbling skills at the elementary school level. The research data were obtained through an in-depth analysis study in 3 national journals on the concept and form of picture and picture learning models, and 3 national journals on soccer dribbling skills at the elementary school level. The results of the analysis of the study indicate that the reciprocal learning model has characteristics that match the characteristics of vocational high school students. The combination obtained realizes the implementation of learning with learning activities to divide the roles of students, namely one as a model and the other as an observer, and vice versa. Students who act as models apply the basketball passing technique by providing an explanation regarding the movements being carried out, while the observer is only tasked with receiving the ball and returning the ball in the normal way (not with the passing technique). The conclusion related to the study is the application of the reciprocal learning model has a role in improving the learning outcomes of basketball passing techniques and can be applied to class X students of Al-Fattah Medan Private Vocational School. Forms of implementation that can be done in basketball passing material using reciprocal learning models are: (1) Students are given the independence to form groups (pairs); (2) Forming a lineup according to the needs and situation of the school environment (field); and (3) The alternation of displays and observers is marked by a whistle signal as a signal. By applying the form of implementation, the goal in achieving basketball passing learning outcomes can be realized with a reciprocal learning model.

\section{Keywords: Study, Reciprocal, Passing Basketball, Covid-19}

\section{PENDAHULUAN}

Pendidikan dalam konteks kurikulum 2013 diorientasikan untuk menghasilkan insan indonesia yang berkarakter yang produktif, kreatif, inovatif, dan efektif melalui penguatan sikap (tahu mengapa), keterampilan (tahu bagaimana), dan pengetahuan (tahu apa) yang terintegrasi. Orientasi ini dilandasi oleh adanya kesadaran bahwa perkembangan kehidupan dan ilmu pengetahuan abad ke-21, telah mengalami pergeseran ciri dibandingkan dengan abad sebelumnya, oleh karena itu seluruh aktivitas siswa selanjutnya harus dikemas dengan proses kerja keilmuan yang berbasis pada saintifik, dengan proses inilah yang akan menjadi ruh bagi pembelajaran konteks kurikulum 2013. Sekolah memiliki pengaruh terhadap perkembangan anak-anak, menurut Santrock : 1995 dalam buku Psikologi Perkembangan mengemukakan bahwa "anak-anak menghabiskan waktu bertahun-tahun di sekolah sebagai anggota suatu masyarakat kecil yang harus mengerjakan tugas dan mengikuti sejumlah aturan yang menegaskan dan membatasi prilaku, perasaan dan sikap mereka". Selain itu menurut Seifert dan Hoffnung (1994) menjelaskan bahwa "Sekolah mempengaruhi perkembangan anak melalui dua kurikulum, yaitu academic curriculum dan hidden 
curriculum. Academic curriculum meliputi sejumlah kewajiban yang diharapkan dikuasai oleh anak. Ia membantu anak memperoleh pengetahuan akademis dan kemempuan intelektual yang dibutuhkan untuk keberhasilan berpartisipasi dalam masyarakat. hidden curriculum meliputi sejumlah norma, harapan, dan penghargaan yang implisit untuk dipikirkan dan dilaksanakan dengan cara-cara tertentu yang disampaikan melalui hubungan social sekolah dan otoritas, khususnya yang berkenaandengan peran sosial guru-siswa dan prilaku yang diharapkan oleh masyarakat". Pendapat di atas dapat disimpulkan bahwa interaksi dengan guru dan teman sebaya di sekolah, memberikan dampak peluang yang besar bagi anak-anak untuk mengembangkan kemampuan kompetensi diri yang terdiri dari aspek pengetahuan, keetrampilan, dan sikap serta mengembangkan konsep diri sepanjang masa pertengahan dan akhir anak-anak. Sekolah merupakan sarana pendidikan formal yang memiliki peran penting dalam pengembangan kepribadian anak. Sekolah yang di selenggarakan oleh pemerintah disebut dengan sekolah negeri. Sekolah negeri diselenggarakan untuk memberikan pendidikan sesuai dengan tujuan pendidikan murni.

Ada juga sekolah yang diselenggarakan non pemerintah disebut sekolah swasta, sekolah swasta mungkin untuk anak-anak dengan kebutuhan khusus ketika pemerintah tidak bisa memberi sekolah khusus pada mereka, seperti sekolah keagamaan,yaitu sekolah Islam, sekolah Kristen dan yang lain-lainnya. Sekolah negeri dan swasta mempunyai karakteristik yang berbeda. Sekolah swasta diselenggarakan untuk memenuhi kebutuhan khusus yang tidak bisa diberikan sekolah negeri, misalnya pendidikan keagamaan yang mendalam atau pendidikan keolahragaan yang mempelajari olahraga lebih dalam. Dalam kurikulum pendidikan terdapat beberapa mata pelajaran salah satuanya adalah pendidikan jasmani danolahraga. Pendidikan Jasmani dan olahraga. Menurut Nadisah (1992:15) adalah bagian secara umum yang berlangsung melalui aktivitas yang melibatkan mekanisme gerak tubuh manusia yang menghasilkan pola-pola perilaku pada individu yang bersangkutan. Dengan demikian pendidikan jasmani, olahraga dan Kesehatan merupakan bagian integral dari pendidikan secara keseluruhan yang menunjang perkembangan siswa melalui aktivitas jasmani. Pendidikan jasmani, olahragadan kesehatan merupakan bagian yang terpenting dari proses pendidikan secara keseluruhan yang pola pencapaian tujuannya menggunakan aktivitas jasmani.Tujuan pendidikan jasmani dan olahraga yang ingin dicapai meliputi tujuan dari segi kognitif, afektif, dan psikomotor. Pendidikan Jasmani Olahraga dan Kesehatan (PJOK) merupakan bagian integral dari proses pendidikan yang diterapkan di sekolah secara keseluruhan. Penjas di sekolah mempunyai peranan yang sangat penting di banding bidang studi lain, karena melalui penjas selain dapat digunakan untuk Pengembangan aspek fisik dan psikomotor, juga ikut berperan dalam pengembangan aspek kognitif dan afektif secara serasi dan seimbang, sehingga penerapannya memberikan kontribusi pada peningkatan kemampuan motorik atau fisik siswa. Kompetensi Inti pada pembelajaran Pendidikan Jasmani Olahraga dan Kesehatan (PJOK) tingkat SMK Kelas X adalah siswa harus memiliki kemampuan dalam menerapkan materi bola besar salah satunya adalah bola basket. Materi bola basket merupakan materi yang memiliki kriteria penerapan berdasarkan fasilitas, sarana, dan prasarana sekolah yang memadai sesuai kebutuhan materi. Dalam penerapan materi bola basket maka, guru harus memiliki kecermatan dalam menentukan gaya belajar atau model pembelajaran yang sesuai dengan kriteria materi pokok yaitu passing dengan karakter siswa. Salah satu model pembelajaran yang memiliki kesamaan dari aspek defenisi dengan materi21 Keterampilan 
Passing Bola Basket Materi Pada PJOK SMK Kelas X Bounch-pass Model Pembelajaran Resiprokal Chest-pass Overhead-pass passing adalah resiprokal. Resiprokal adalah model pembelajaran timbal balik atau dengan kata lain merupakan model pembelajaran kelompok yang saling berpasangan. Sehubungan dengan teknik passing, maka resiprokal memiliki kesesuaian dengan rangkaian gerakan materi yaitu gerakan saling berhadapan dengan memberi dan menerima bola antar rekan satu tim. Teknik passing dalam bola basket pada tingkat SMK kelas $\mathrm{X}$ adalah siswa harus mampu melakukan seluruh jenis passing diantaranya adalah chest pass, bounch pass, dan overhead pass. Ketiga bentuk passing tersebut merupakan kemampuan mendasar yang harus dikuasai untuk dapat masuk pada level materi permainan dan peraturan di kelas XI dan XII. Sehingga materi passing ini lah sangat diprioritaskan sebagai materi di kelas X.

\section{METODE PENELITIAN}

Penelitian ini menggunakan metode kualitatif dengan pendekatan studi kasus. Pendekatan studi kasus merupakan strategi penelitian di mana di dalamnya peneliti menyelidiki secara cermat suatu peristiwa, aktivitas, proses, program atau sekelompok individu. Kasus-kasus dibatasi oleh waktu dan aktivitas, peneliti mengumpulkan informasi secara lengkap dengan menggunakan berbagai prosedur pengumpulan data berdasarkan waktu yang telah ditentukan (Creswell, 2014:20). Sedangkan menurut (Bungin \& M.Burhan, 2007:68) desain deskriptif kualitatif bertujuan untuk menggambarkan, meringkaskan berbagai kondisi, berbagai situasi, atau berbagai fenomena realitas sosial yang ada di masyarakat yang menjadi objek penelitian, dan berupaya menarik kesimpulan itu ke permukaan sebagai suatu ciri, karakter, model, tanda, atau gambaran tentang kondisi, situasi, maupun fenomena tertentu. Hal ini senada dengan yang dikemukakan Bogdan and Taylor dalam (Moleong, 2007:3) mendefinisikan metodologi kualitatif sebagai prosedur penelitian yang menghasilkan data deskriptif berupa kata-kata tertulis atau lisan dari orangorang dan perilaku yang diamati. Tahapan dalam penelitian ini terdiri dari kegiatan : 1) pengumpulan data terkait kajian-kajian yang terdapat pada jurnal penelitian yang meliputi variabel "Model Pembelajaran Resiprokal" dan "Keterampilan Passing Bola Basket"; 2) melakukan analisis terhadap variable ; 3) melakukan analisis hubungan terhadap antara variabel; dan 4) menemukan kesimpulan dari studi analisis. Dalam penelitian kualitatif, di dalamnya peneliti terlibat dalam pengalaman yang berkelanjutan dan terus-menerus dengan para informan. Keterlibatan inilah yang nantinya memunculkan serangkaian isu-isu strategis, etis dan personal dalam penelitian kualitatif (Bungin \& M.Burhan, 2007:65). Peran peneliti menentukan penjelasan tentang masalah-masalah yang mungkin muncul dalam proses pengumpulan data. Langkah-langkah pengumpulan data meliputi usaha membatasi penelitian, mengumpulkan informasi melalui angket, dokumentasi, materi-materi visual, serta merancang protokol untuk merekam/ mencatat informasi. Peneliti mengumpulkan beragam jenis data dan memanfaatkan waktu seefektif mungkin untuk mengumpulkan informasi di lokasi penelitian. Teknik keabsahan data dalam penelitian ini dilakukan dengan

Teknik ketekunan pengamatan, teknik ini digunakan untuk memperoleh data yang akurat dan sahih. Sejalan dengan itu peneliti bersikap disiplin, tekun dan cermat dalam pencatatan dan pengumpulan data. Ketekunan pengamatan bermaksud menemukan ciri-ciri dan unsur-unsur situasi yang sangat relevan dengan persoalan atau isu-isu yang sedang dicari dan kemudian memusatkan diri pada hal-hal tersebut secara rinci. Menurut Lincoln dan Guba dalam Trochim 2008 (dalam Emzir, 2012:79) menerangkan bahwa ada empat 
kriteria untuk menilai kualitas penelitian kualitatif yaitu kredibilitas (setara dengan validasi internal), transferabilitas (setara dengan validasi eksternal), dependabilitas (setara dengan reliabilitas), dan konfirmabilitas (setara dengan objektivitas). Berdasarkan hal di atas peneliti melakukan keabsahan data dengan :25 1) Kredibilitas (credibility) atau dapat dipercaya : peneliti melakukan analisis jurnal sebagai orang yang memiliki pemahaman yang mendalam tentang pokok bahasan, ketekunan penelitian, dan diskusi teman sejawat yang memiliki keahlian dalam bidang pokok kajian. 2) Transferabilitas (transferability) atau digeneralisasikan atau ditransfer : peneliti melakukan deskripsi konteks kajian dan asumsiasumsi yang terjadi secara sentral pada penelitian. 3) Dependabilitas (dependability) atau sama dengan reliabilitas atau ketetapan : peneliti melakukan pemeriksaan kembali terkait catatan yang dibuat berdasarkan hasil analisis pokok kajian, sehingga data yang diperoleh memiliki ketepatan dan kesesuaian. 4) Konfirmabilitas (confirmability) atau sama dengan objektivitas : peneliti mendokumentasikan prosedur pengamatan sebagai cara untuk mengecek dan mengecek kembali seluruh data. Sehingga data dapat dikonfirmasi atau dipahami oleh orang lain.

\section{HASIL DAN PEMBAHASAN}

Kajian terkait model pembelajaran resiprokal berdasarkan hasil penelitian yang diterbitkan jurnal nasional adalah sebuah model yang memiliki ciri khas pada aktivitas instruksional di mana siswa menjadi guru di sesi membaca kelompok kecil. Guru Model, kemudian membantu siswa belajar untuk memandu diskusi kelompok menggunakan empat strategi: meringkas, menghasilkan pertanyaan, mengklarifikasi, dan memprediksi. Reciprocal Teaching merupakan salah satu alat yang bisa meningkatkan pemahaman dan memonitor pemahaman siswa. Dalam pengajaran ini, guru dan siswa bergiliran menjadi guru untuk mendorong terjadinya diskusi tentang materi bacaan. Model resiprokal merupakan salah satu model pembelajaran yang menekankan pada pemahaman dalam membaca. Pembelajaran resiprokal digunakan untuk membantu siswa memusatkan perhatian pada apa yang sedang dibaca dan membuat siswa memahami bacaannya. Dari beberapa pemaparan di atas dapat diambil kesimpulan bahwa kelebihan dan kekurangan Reciprocal teaching sebagai berikut: (1) dapat melatih siswa untuk belajar tanpa guru; (2) menumbuhkan keberanian untuk menyampaikan pendapat; (3) melatih siswa untuk menemukan hal-hal penting dari apa yang dipelajari. Adapun kelemahannya adalah: (1) kurang kesungguhan siswa dalam berperan sebagai guru siswa; (2) kurang memperhatikan pelajaran hanya memperhatikan aktifitas siswa; (3) membutuhkan waktu yang cukup lama. Untuk mengatasi dan mengurangi dampak kelemahan model pembelajaran Reciprocal teaching, peneliti dan guru selalu47 memberikan bimbingan dan pengarahan dalam berbagai kesempatan. Motivasi siswa menjadi bagian penting untuk menumbuhkan kesadaran pada diri siswa terhadap keseriusan pembelajaran.

Kajian terkait keterampilan passing bola basket tingkat sekolah menengah kejuruan diperoleh karakteristik yaitu suatu teknik dasar yang terdiri atas 3 bentuk pelaksanaan yaitu chest pass atau passing setinggi dada, bounce pass atau passing memantul, dan overhead pass atau passing di atas kepala. Passing merupakan cara tercepat mengirim bola yang dilakukan dengan kedua tangan setinggi dada (two hand chest pass). Adapun cara melakukan passing pegang bola dengan kedua tangan jari-jari kedepan, ibu jari berada pada belakang bola sewaktu melakukan operan tarik bola kembali kedada, putar sehinga ibu jari 
berada dibawah bola. Selanjutnya melangkahlah dengan kaki yang berada didepan sementara mendorong tangan lurus kedepan. Jenis operan ini merupakan operan yang paling sering di gunakan dalam permainan bola basket.

Passing bertujuan untuk mengoper bola dari pemain satu kepada lainnya untuk menjalin kerjasama. Passing bisa dilakukan dengan menggunakan dua atau satu tangan. Passing yang dilakukan secara taktis, tepat waktu, dan akurat dapat menciptakan peluang untuk membuat angka. Melalui passing yang tepat dan48 akurat akan menciptakan tim yang baik. Pelaksanaan passing dan tangkapan yang baik penting bagi permainan tim, dan keahlian seperti itulah yang membuat bolabasket menjadi permainan tim yang indah. Selanjutnya passing merupakan keterampilan bermain pertama bolabasket, sebab dengan cara inilah pemain dapat melakukan gerakan mendekati ring (basket) dan seterusnya melakukan tembakan.

Analisis terhadap kajian model pembelajaran resiprokal dengan keterampilan passing bola basket sekolah menengah kejuruan memiliki hubungan dalam penerapannya dalam pembelajaran Pendidikan Jasmani Olahraga dan Kesehatan (PJOK). Penerapan pembelajaran resiprokal memiliki karakteristik yang sesuai dengan karakteristik siswa sekolah menengah kejuruan. Model pembelajaran resiprokal dilakukan dengan konsep timbal balik atau secara bergantian. Pedoman utama pada pelasanaan model pembelajaran adalah guru dan siswa dengan teknis bergiliran menjadi guru untuk mendorong terjadinya diskusi tentang materi bacaan. Karaktersitik pada teknik passing bola basket merupakan suatu gerakan yang dilakukan dengan cara tercepat mengirim bola dengan kedua tangan setinggi dada. Passing bertujuan untuk mengoper bola dari pemain satu kepada lainnya untuk menjalin kerjasama. Passing bisa dilakukan dengan menggunakan dua atau satu tangan. Passing yang dilakukan secara taktis, tepat waktu, dan akurat dapat49 menciptakan peluang untuk membuat angka. Melalui passing yang tepat dan akurat akan menciptakan tim yang baik. Pelaksanaan passing dan tangkapan yang baik penting bagi permainan tim, dan keahlian seperti itulah yang membuat bolabasket menjadi permainan tim yang indah. Selanjutnya passing merupakan keterampilan bermain pertama bolabasket, sebab dengan cara inilah pemain dapat melakukan gerakan mendekati ring (basket) dan seterusnya melakukan tembakan. Penerapan model pembelajaran resiprokal pada penerapan materi Teknik passing bola basket dilakukan dengan berpasangan dan membagi peran kepada siswa yaitu satu sebagai peraga dan lainnya menjadi pengamat, begitu juga dengan sebaliknya. Siswa yang menjadi peraga, menerapkan teknik passing bola basket dengan sambil memberikan penjelasan terkait gerakan yang dilakukan, sedangkan untuk pengamat hanya bertugas menerima bola saja dan mengembalikan bola dengan cara biasa (bukan dengan teknik passing). Peraga akan terbentuk kemampuannya dalam menjelaskan (kognitif) dan terkontrol dalam melakukan gerakan passing yang terdiri dari chest pass, bounce pass, dan overhead pass. Sedangkan pengamat akan memberikan penilaian terkait teknik yang dilakukan peraga sebagai bahan refleksi diskusi. Setelah beberapa repetisi dilakukan, teknik peran kelompok dilakukan secara bergantian yaitu peraga akan menjadi pengamatan dan pengamatan akan menjadi peraga (timbal balik) sehingga dengan berperannya siswa untuk menjadi peraga dan pengamatan akan meningkatkan penguasaan siswa pada teknik passing bola basket melalui konsep peraga sebagai bentuk keterampilan, dan pengamatan sebagai bentuk pengetahuan.

Berdasarkan uraian tersebut menunjukkan bahwa model pembelajaran resiprokal memiliki peran dalam meningkatkan hasil belajar teknik passing bola basket dan dapat 
diterapkan pada siswa kelas X SMK Swasta Al-Fattah Medan. Bentuk implementasi yang dapat dilakukan dalam materi passing bola basket dengan menggunakan model pembelajaran resiprokal adalah : 1) Siswa telah diberikan penjelasan dan latihan awal terkait materi passing bola basket. 2) Siswa diberikan kemandirian untuk membentuk kelompok (pasangan) 3) Membentuk susunan barisan sesuai kebutuhan dan situasi lingkungan sekolah (lapangan) 4) Penerapan pergantian peraga dan pengamat ditandai dengan aba-aba peluit sebagai isyarat. dengan menerapkan bentuk implementasi, maka tujuan dalam mencapai hasil belajar passing bola basket, dapat diwujudkan dengan model pembelajaran resiprocal.

\section{KESIMPULAN}

Penelitian Analisis terhadap kajian model pembelajaran resiprokal denga keterampilan passing bola basket, dapat dirumuskan dan kemudia direkomendasikan khsusunya pada Sekolah Menengah Kejuruan Swasta Al-Fatta Medan pada masa Pendemi Corona Virus Desease-19 dilakukan dengan stud pustaka jurnal nasional. Kajian dilakukan dengan menemukan karakteristi konsep model pembelajaran resiprokal dan karakteristik keterampilan passin bola basket. Hasil analisis kajian menunjukkan bahwa model pembelajara resiprocal memiliki karakteristik yang sesuai dengan karakteristik siswa sekola menengah kejuruan Perpaduan yang diperoleh mewujudkan implementasi pembelajaran dengan kegiatan belajar membagi peran kepada siswa yaitu satu sebagai perag dan lainnya menjadi pengamat, begitu juga dengan sebaliknya. Siswa yan menjadi peraga, menerapkan teknik passing bola basket dengan sambal memberikan penjelasan terkait gerakan yang dilakukan, sedangkan untuk pengamat hanya bertugas menerima bola saja dan mengembalikan bola dengan cara biasa (bukan dengan teknik passing). Peraga akan terbentuk kemampuannya dalam menjelaskan (kognitif) dan terkontrol dalam melakukan gerakan passing yang terdiri dari chest pass, bounce pass, dan overhead pass. Sedangkan pengamat akan memberikan penilaian terkait teknik yang dilakukan peraga52 sebagai bahan refleksi diskusi. Setelah beberapa repetisi dilakukan, teknik peran kelompok dilakukan secara bergantian yaitu peraga akan menjadi pengamatan dan pengamatan akan menjadi peraga (timbal balik) sehingga dengan berperannya siswa untuk menjadi peraga dan pengamatan akan meningkatkan penguasaan siswa pada teknik passing bola basket melalui konsep peraga sebagai bentuk keterampilan, dan pengamatan sebagai bentuk pengetahuan.

Penerapan model pembelajaran resiprokal memiliki peran dalam meningkatkan hasil belajar teknik passing bola basket dan dapat diterapkan pada siswa kelas X SMK Swasta AlFattah Medan. Bentuk implementasi yang dapat dilakukan dalam materi passing bola basket dengan menggunakan model pembelajaran resiprokal adalah : (1) Siswa telah diberikan penjelasan dan Latihan awal terkait materi passing bola basket; (2) Siswa diberikan kemandirian untuk membentuk kelompok (pasangan); (3) Membentuk susunan barisan sesuai kebutuhan dan situasi lingkungan sekolah (lapangan); dan (4) Penerapan pergantian peraga dan pengamat ditandai dengan aba-aba peluit sebagai isyarat. Dengan menerapkan bentuk implementasi, maka tujuan dalam mencapai hasil belajar passing bola basket, dapat diwujudkan dengan model pembelajaran resiprocal. 
Jumper : Jurnal Mahasiswa Pendidikan Olahraga

Vol. 1, No.2, Mei 2021

\section{DAFTAR PUSTAKA}

Badan Standar Nasional Pendidikan. (2006). Panduan Penyusunan Kurikulum Tingkat Satuan Pendidikan Jenjang Pendidikan Dasar dan Menengah Jakarta: BNSP.

Depdiknas. Undang-Undang Republik Indonesia tentang Sistem Pendidikan Nasional (2003). Indonesia.

Edukatif, B., \& Alam, B. (2018). Jurnal Pendidikan Jasmani dan Olahraga, 3(1), 41-51. https://doi.org/10.17509/jpjo.v3i1.10612

Giriwijoyo, S., \& Sidik, D. Z. (2013). Ilmu Kesehatan Olahraga. Bandung: Rosda.

Huda, M. (2014). Model-Model Pengajaran dan Pembelajaran. Yogyakarta: Pustaka Pelajar. Permendiknas. Standar Proses Pembelajaran, Pub. L. No. 41 (2007). Jakarta.

Rahayu, E. T. (2013). Strategi Pembelajaran Pendidikan Jasmani. Bandung: Alfabeta.

Rahman, M. H. (2016). Pengaruh Model Pembelajaran Dan Gaya Mengajar Guru Tehadap Prestasi Belajar Siswa Pada Mata Pelajaran Pkn. Jurnal Penelitian Dan Pendidikan IPS (JPPI) Volume, 10(3), 337-344.

Rahyubi, H. (2014). Teori-Teori Belajar dan Aplikasi Pembelajaran Motorik. Bandung: Nusa Media.

Sugiyono. (2011). Metode Penelitian Kombinasi (Mixed Methods). Bandung: Alfabeta.

Usman, K., Soekardi, \& Pramono, H. (2016). Pengaruh Model Pembelajaran Dan Tingkat Koordinasi Mata Tangan Terhadap Hasil Belajar Bola Basket. Journal of Physical Education and Sport, Universitas Negeri Semarang, 5(1), 53-59. https://doi.org/10.5897/JPESM

Utami, R. (2006). Pendidikan Jasmani Olah Raga, dan Kesehatan. Surakata: CV. Teguh Karya. 